\title{
PLATO OR PLAUTUS? (JEROME, EPIST. XXII 30, 2)'
}

In Jerome's account of his "dream» the manuscripts are divided between Plautus and Plato; all editors have preferred Plautus. It would seem however that the correct reading is Plato. The assumption is supported by Jerome's low estimate of Plautus and by the likelihood that he read Plato to improve his Greek; Jerome will also have been eager to advertise his familiarity with Plato precisely because he had so little aptitude for philosophy. Finally Plato makes a better antithesis to scripture.

Towards the end of his Libellus de uirginitate seruanda Jerome tells the famous story of his "dream»: he was haled before God's judgmentseat and told Ciceronianus es, non Christianus $(30,4)$. The account is introduced as an illustration of the precept not to be «over-eloquent» $(29,6)$. Jerome accordingly begins by describing how as an ascetic in the East he had been put off by the uncouth language of scripture: si quando... prophetam legere coepissem, sermo horrebat incultus $(30,2)$. It was therefore the Classics which he had read in his leisure hours: itaque miser ego lecturus Tullium ieiunabam. post noctium crebras uigilias, post lacrimas, quas mihi praeteritorum recordatio peccatorum ex imis uisceribus eruebat, Plautus sumebatur in manibus (ibid.). In the last clause Hilberg's manuscripts are equally divided between the readings Plautus and Plato ${ }^{2}$. It is the purpose of the present article to argue that the correct reading is Plato.

' Citation of Latin works follows the method of Thesaurus Linguae Latinae: Index Librorum Scriptorum Inscriptionum, Leipzig $1990_{2}$. For Latin Fathers the editions used are those given in H. J. Frede, Kirchenschriftsteller: Verzeichnis und Sigel, Freiburg/B. 1981 (Vetus Latina 1/1), and in the same author's Kirchenschriftsteller: Aktualisierungsheft, Freiburg/B. 1984 (Vetus Latina 1/1A) and Kirchenschriftsteller: Aktualisierungsheft, Freiburg/B. 1988 (Vetus Latina 1/1B). Greek patristic works are cited according to the conventions adopted in G. W. H. Lampe, A Patristic Greek Lexicon, Oxford 1961-8, pp. XI-XLV; the editions used are those given in M. Geerard and F. Glorie, Clavis Patrum Graecorum, I-V, Turnhout 1974-87.

${ }^{2}$ I. Hilberg, Sancti Eusebii Hieronymi Epistulae, I, Vienna-Leipzig 1910 (CSEL 
Lübeck had maintained that Plato could not be right on the grounds that his enquiry into Jerome's sources seemed to provide no evidence of direct acquaintance with the philosopher's works ${ }^{3}$. Nonetheless the reading Plato was then defended by Schuster ${ }^{4}$. His reasoning was twofold. In the first place he argued that Plautus was only a conjecture; this view was however due to a misreading of Hilberg's appara$t_{\text {tus }}{ }^{5}$. Secondly Schuster adduced an argument of a more general nature. Paganism and christianity had gradually achieved a modus uiuendi: Tertullian, Lactantius and Augustine all drew on Plato. The case which Schuster made was unimpressive: it has accordingly failed to find adherents ${ }^{6}$. Nor has the question been reopened. Recently Hagendahl has observed that Jerome is the only Father who shows a "grösseres Interesse" for Plautus; as the chief evidence for this assertion he adduces Jerome's account of his dream?

There would seem however to be very little reason for supposing that Plautus is in fact the right reading. Elsewhere Hagendahl assembles all the passages in Jerome which show Plautine influence ${ }^{8}$. He notes that there are just two direct quotations: neither of them is literal. Moreover Hagendahl is able to cite only three further passages of Plautus that find an echo in Jerome's very extensive oeuvre ${ }^{9}$. This lack of reso-

$54)$, p. 189. Hilberg never published a proper prolegomena setting out the principles he had followed in constructing his text.

${ }^{3}$ E. Lübeck, Hieronymus quos noverit scriptores et ex quibus hauserit, Leipzig 1872 , p. 106, n. 2.

${ }^{4}$ M. Schuster, "Zu Hieronymus und Eucherius», Philologische Wochenschrift 49, 1929 , pp. $190-192$.

5 This is a "negative" apparatus: MSS are only cited for readings other than the one adopted. Plautus is in fact found in three of Hilberg's MSS.

'Cf. J. B. Bauer, «Hieronymus und Ovid", Grazer Beiträge 4, 1975, pp. 13-19, on p. 14, n. 10: «Der Vorschlag M. Schuster's... Plato statt Plautus zu lesen, hat sich mit Recht nicht durchgesetzt».

$7 \mathrm{H}$. Hagendahl, Von Tertullian zu Cassiodor: Die profane literarische Tradition in dem lateinischen christlichen Schrifttum, Göteborg 1983 (Stud. Graec. et Lat. Gothob. 44), p. 78 and p. 141, n. 203: "Die Hauptstelle ist der Bericht von Hieronymus' Traum".

${ }^{8}$ H. Hagendahl, Latin Fathers and the Classics: A Study on the Apologists, Jerome and Other Christian Writers, Göteborg 1958 (Acta Univ. Gothob. 64, 2), pp. 269270. Lübeck, op. cit. (n. 3), p. 8, had already been struck by the paucity of Jerome's borrowings from Plautus; however he referred to the present passage of the Libellus de uirginitate in order to show that Jerome neque a Plauto... prorsus se abstinuit.

9 In a review of Hagendahl's work I. Opelt, Jahrbuch für Antike und Christentum 3,1960 , pp. 146-148, on p. 147, criticizes the author for failing to consider the possibility of quotation at second hand. She observes that «mit dieser Möglichkeit ist... für die... Plautuszitate zu rechnen". It may also be observed that the few passages in which Ambrose appears to echo Plautus are dismissed as merely proverbial by $\mathbf{P}$. Courcelle, "Ambroise de Milan face aux comiques latins", Revue des Études Latines 50, 1972, pp. 223-231, on pp. 224-225 (= P. Courcelle, Recherches sur Saint 
nance is all the more remarkable, since Jerome displays an extraordinary propensity to take over phraseology from other writers ${ }^{10}$. Hagendahl also expresses surprise that such Plautine echoes as can be discovered in Jerome belong to the second half of his career; in the earlier period the supposed allusion to Plautus in the Libellus stands alone ". It may be felt that if Jerome had really been an assiduous student of Plautus in the 370's, such reading would have left at least some trace on his early work.

Jerome's purpose in this passage of the Libellus is to warn his reader against an excessive attachment to eloquence. The two classical authors he mentions must therefore be models of literary refinement who can provide an effective contrast to the uncouthness of scripture. Such is unquestionably the case with Cicero. It may however be doubted whether the same is also true of Plautus.

Jerome does indeed refer on one occasion to Plautina eloquentia. Here he is replying to a critic who had insisted that translation must be slavishly literal: 'debueras', inquit, 'dicere: oportebat nos, dilecte, non aestimatione clerorum ferri'. hace est Plautina eloquentia, hic lepos Atticus et Musarum, ut dicunt, eloquio conparandus! (epist. LVII 12, 3). Jerome's sarcastic exclamation invites comparison with a passage of Quintilian: in comoedia maxime claudicamus. licet Varro 'Musas', Aeli Stilonis sententia, 'Plautino' dicat 'sermone locuturas fuisse, si Latine loqui uellent'... uix leuem consequimur umbram, adeo ut mihi sermo ipse Romanus non recipere uideatur illam solis concessam Atticis uenerem (inst. X 1, 99-

Ambroise: "Vies" Anciennes, culture, iconographie, Paris 1973, pp. 42-43). Nonetheless Plautine influence on the De Helia is posited by G. Jackson, "Una pagina plautina nel De Helia di Ambrogion, Vichiana 6, 1977, pp. 231-240. Jackson significantly begins with the following remark: "Che Plauto potesse esser letto nel periodo in cui Ambrogio operò, lo attesta espressamente Girolamo (epist. XXII 30, 1 ss.: Plautus sumebatur in manibus)" (p. 231, n. 1). For Augustine Plautus is a "mere name» according to $\mathrm{H}$. Hagendahl, Augustine and the Latin Classics, II, Göteborg 1967 (Stud. Graec. et Lat. Gothob. 20, 2), p. 691.

${ }^{10} \mathrm{Cf}$. the present writer, "Some Features of Jerome's Compositional Technique in the Libellus de uirginitate seruanda (Epist. 22)", Philologus 136, 1992, pp. 234-255. Hagendahl lists some thirty-five passages from Terence alone that are copied by Jerome; cf. op. cit. (n. 8), pp. 270-273 and id., "Jerome and the Latin Classics", Vi Tliae Christianae 28, 1974, pp. 216-227, on p. 217. A further Terentian borrowing in the Libellus de uirginitate is added by the present writer, "Terence's Eunuchus and Jerome", forthcoming in Rheinisches Museum. In this connection it should be recalled that Terence wrote only six plays, whereas there are no fewer than twenty-one by Plautus.

$"$ Op. cit. (n. 8), p. 270: "It is remarkable that there are no traces of Plautine influence in the writings until A. D. 393, if we leave out of consideration the isolated mention of Plautus in Epist. XXII (A. D. 384)». Hagendahl is accordingly obliged to assume that Jerome began to re-read Plautus from 393 onwards. 
100). In both passages there is the same reference to "Plautine speech", to the "language of the Muses", and to "Attic charm»; evidently therefore Jerome is borrowing from Quintilian ${ }^{12}$. Since Jerome's words turn out to be mere plagiarism, they accordingly afford no insight into his own view of Plautus. It may in any case be observed that here Quintilian's attitude to the poet is critical. This passage of Jerome cannot therefore be adduced as evidence that he regarded Plautus as a model of rhetorical finesse ${ }^{13}$.

What Jerome says elsewhere would seem in fact to indicate that refinement was the last quality with which he associated Plautus. In another letter from the same period Jerome refers to his critics in the following terms: inuenti sunt Plautinae familiae et scioli tantum ad detrahendum (epist. XLIX 18, 3) ${ }^{14}$. Here Duval sees an echo of Minucius Felix' Octauius: homo Plautinae prosapiae, ut pistorum praecipuus, ita postremus philosophorum $(14,1)^{15}$. This passage has been the subject of much debate; however it is now generally understood as a reference

12 On the intimacy of Jerome's acquaintance with this author cf. Lübeck, op. cit. (n. 3), pp. 213-218; Hagendahl, op. cit. (n. 8), pp. 294-296. Nonetheless Jerome's debt to Quintilian here escaped the notice of G. J. M. Bartelink, Hieronymus: Liber de optimo genere interpretandi (Epistula 57). Ein Kommentar, Leiden 1980 (Mnemosyne Suppl. 61), pp. 113-114 (ad loc.). He qualifies lepus (sic) Atticus as "eine traditionelle Wendung»; however Thes. Ling. Lat. VII 2, 2 (1970-79), coll. 1176, 84 1177,1 (s. u. lepos), adduces only Martial 111 20, 9. Similarly Musarum, ut dicunt, eloquio conparandus is explained as "eine proverbiale Wendung"; however no other example is supplied by either A. Otto, Die Sprichwörter und sprichwörtlichen Redensarten der Römer, Leipzig 1890, p. 235 (no. 1177), or by R. Häussler, Nachträge zu A. Otto: Sprichwörter und sprichwörtliche Redensarten der Römer, Hildesheim 1968. Oddly enough the presence in Jerome of a phrase like ut dicunt would often seem to indicate that he is in fact borrowing from a specific source; cf. the present writer, "Istae sunt, quae solent dicere: Three Roman Vignettes in Jerome's Libellus de uirginitate seruanda (Epist. 22)», Museum Helveticum 49, 1992, pp. 131-140, on p. 139 with n. 49.

${ }_{13}$ An explicitly pejorative sense is assigned to Plautina eloquentia in this passage by P. Lardet, S. Jérôme: Apologie contre Rufin. Commentaire du livre premier, I, unpubl. diss. Paris 1980, p. 192. Instead of referring to Quintilian he connects the formulation with Plautino... sale at adu. Rufin. I 13. There the application is undoubtedly derogatory; the passage is discussed below. Lardet accordingly sees in haec est Plautina eloquentia, hic lepos Atticus... a collocation of «expressions apparemment contradictoires"; he resolves the difficulty by saying that «il faut entendre cet 'atticisme' par antiphrasen. At the same time Lardet accepts the reading Plautus in the account of Jerome's dream (ibid. p. 193); he is untroubled by the evident contradiction.

${ }_{14}$ A similar formulation is found in epist. L 1, 2: dialecticum urbis uestrae et Plautinae familiae columen. It will be argued in a future paper that here the correct reading is in fact Platonicae, not Plautinae.

is Y.-M. Duval, "La lecture de l'Octavius de Minucius Felix à la fin du $v^{\mathrm{e}}$ siècle», Revue des Études Augustiniennes 19, 1973, pp. 56-68, on p. 61. 
either to Plautus' employment as a miller's labourer ${ }^{16}$ or to the coarse and vituperative tone of his plays ${ }^{17}$. Clarke glosses Jerome's own formulation as follows: "he uses it of ill-educated and ill-informed abusive braggarts, like many a Plautine comic figure» ${ }^{18}$.

A second passage may be adduced in this connection. Jerome's Apology against Rufinus contains the phrase Plautino in me sale ludere (I 13). Here the issue is Jerome's Hebrew mentor: Rufinus had tastelessly changed his name from Baranina to Barabbas. Lardet notes that Plautino... sale is an imitation of Horace's Ars Poetica (11. 270-271) ${ }^{19}$. He also observes that in this passage Horace is highly critical of Plautus' literary style ${ }^{20}$. Lardet accordingly concludes that Jerome's own attitude to Plautus is similarly unfavourable: «Plaute est le type du comique sans finesse".

It would appear from the foregoing that Jerome's opinion of Plautus was indeed less than enthusiastic ${ }^{21}$; it is therefore hard to believe that in the account of his dream Jerome should have mentioned the comic poet alongside Cicero as one of his two favourite authors and as a model of literary refinement in contrast to the bible ${ }^{22}$. At the same time Rufinus applies the following description to Jerome: dum totus Plautinae et Tullianae cupis eloquentiae sectator uideri (apol. adu. Hier. II 13).

${ }^{16}$ Cf. (e. g.) E. Magaldi, «Della controversia su 'homo Plautinae prosapiae ecc.' (Min. Fel., Octav. XIV 1)", Didaskaleion N. S. 7, 1929, pp. 41-52, on p. 50: "Ë probabile allora che colui il quale volesse rimproverare ad un altro di essere un pessimo ingegno, degno piuttosto di essere mandato ad pistrinum, lo apostrofasse come homo Plautinae prosapiae, Plauto offrendogli l'esempio del poeta-manovale". In this connection G. W. Clarke, "Four Passages of Minucius Felix", in P. Granfield and J. A. Jungmann (edd.), Kyriakon: Festschrift Johannes Quasten, II, Münster/W. 1970, pp. 499-507, on p. 505, observes: "Pistor was a by-word for unreflecting stupidity, his work the nadir of banausic drudgery".

${ }^{17}$ Cf. (e. g.) J. Beaujeu, Minucius Felix: Octavius, Paris 1964, p. 95: "dans le style des dialogues de Plaute, riches en injures et en grossièretés». For other interpretations cf. M. Pellegrino, M. Minucii Felicis Octavius, Turin 1947 (Scrittori Latini commentati per le scuole, 173), pp. 114-116.

18 Art. cit. (n. 16), p. 504.

19 Op. cit. (n. 13), p. 192.

${ }^{20}$ At uestri proaui Plautinos et numeros et / laudauere sales, nimium patienter utrumque, / ne dicam stulte, mirati, si modo ego et uos / scimus inurbanum lepido seponere dicto / legitimumque sonum digitis callemus et aure (11. 270-274).

${ }^{21}$ Jerome notes that Plautus translated idiomatically from the Greek at epist. LVII 5, 5 and CVI 3, 3. In both passages the name is linked with Terence and Caecilius; in the first Jerome is endeavouring to justify his own practice of doing the same.

${ }^{22} \mathrm{H}$. Jürgens, Pompa diaboli: Die lateinischen Kirchenväter und das antike Theater, Stuttgart 1972 (Tüb. Beitr. z. Altertumswiss. 46), p. 91, refers to Claudianus Mamertus, epist. 2 pp. 205, 30 - 206, 3, where Plautus' style is commended. However this late fifth-century author was an archaizer (cf. ibid. p. 66); in the same sentence he also recommends Naevius, Cato and Gracchus. 
Hagendahl assumed that these words were a reference to the Libellus de uirginitate; he was nevertheless uncomfortable about the mention of Plautus ${ }^{23}$. Marti has however suggested that Rufinus is in fact thinking of Jerome's fifty-seventh letter ${ }^{24}$. The evidence which can be adduced in support of this interpretation would seem to be substantial.

In his letter fifty-seven to Pammachius Jerome had spoken of Plautina eloquentia $(12,3)$; this ironic comment on the sort of uncouthly literal translation which Jerome himself eschews was discussed above. It may also be noted that there is an exact verbal correspondence between this text and Rufinus' Apology: the same phrase Plautina eloquentia occurs in both. Cicero is likewise present in Jerome's letter to Pammachius, for in the immediately preceding chapter Jerome had employed a similarly sarcastic exclamation: re uera sensus rhetoricus et declamatio Tulliana $(11,1)$. Moreover in this work Jerome states explicitly that Cicero is his model in elegant and idiomatic translation: habeoque huius rei magistrum Tullium $(5,2)$. Such an admission fits Rufinus' wording perfectly: cupis... sectator uideri. In the Libellus on the other hand Jerome professes to have given up his attachment to the classics in favour of scripture. Marti himself observed that Rufinus makes overt reference to letter fifty-seven throughout this section of his Apology ${ }^{25}$. It would appear therefore that Rufinus has the same work in mind when he speaks of Plautina et Tulliana eloquentia ${ }^{26}$.

If then there is no real evidence to support the reading Plautus in Jerome's Libellus de uirginitate, some strong arguments can be adduced for rejecting it. Plautus' works are concerned with worldliness in general and with the wiles of the flesh in particular. They accordingly make highly inappropriate reading for an ascetic. It is even less plausible that

${ }^{23} \mathrm{Op}$. cit. (n. 8), p. 269: «Plautus appears together with Cicero in the account Jerome gives of his dream. Because of that, it would seem, Rufinus points out those two as Jerome's principal models in matter of style, which certainly goes too far as to Plautus». Rufinus' statement is also regarded as an allusion to the Libellus by Jürgens, op. cit. (n. 22), p. 89.

${ }^{24} \mathrm{H}$. Marti, Ubersetzer der Augustin-Zeit: Interpretation von Selbstzeugnissen, Munich 1974 (Stud. et Testim. Ant. 14), p. 194. Marti offers no arguments to corroborate his suggestion; he merely remarks that «epist. 57 ist R. in der Apoll gie sowieso gegenwärtig». Marti's view is accepted by Bartelink, op. cit. (n. 12), p. 113.

${ }_{25}$ Viz. 2, 8; 2, 31. The letter had been published a relatively short time before Rufinus began his Apology.

${ }^{26}$ No inference can of course be drawn from Rufinus' wording as to his estimate of Plautus' literary merit. The phrase Plautina eloquentia will simply have been appropriated from Jerome's letter; here Jerome himself was borrowing from Quintilian. Rufinus was no connoisseur of classical literature; cf. F. X. Murphy, Rufinus of Aquileia (345-411): His Life and Works, Washington 1945 (Cath. Univ. of Am. Stud. in Med. Hist. N. S. 6), pp. 8-11. 
plays of such scabrous content would have been the main object of study for someone who wrestled as implacably as Jerome against sexual temptation: one needs only to recall the grim description of his struggle in chapter seven of the Libellus ${ }^{27}$. It may also be observed that Jerome speaks of his self-mortifications in the very same sentence as the putative allusion to Plautus ${ }^{28}$. Only a few months earlier he had castigated priests who read comedies ${ }^{29}$. Clearly therefore a reference to Plautus is mal à propos in-the Libellus de uirginitate seruanda: one expects instead a serious author who makes a suitable correlate to Cicero.

Moral reasons are not the only ones for rejecting the reading Plautus. There are also literary grounds for suspicion: Plautus does not figure among the writers that Jerome cites in similar contexts elsewhere. In the prelude to the account of his dream it is Horace, Vergil and Cicero whom Jerome condemns as authors that are incompatible with the study of scripture $(29,7)$. Of these Cicero duly recurs in the narrative of the dream. However it is somewhat disconcerting to find that he is now paired with Plautus. The incongruity is eliminated if Plato is read instead: as a Greek he was naturally excluded from the earlier enumeration in which Jerome is telling a Latin audience what writers to avoid. A further observation may be made. On a number of occasions Jerome gives a list of the various Latin authors he stopped reading when the study of scripture became his sole preoccupation ${ }^{30}$. Here Plautus is significantly never mentioned.

If a comic poet was to be introduced into the dream narrative at all, it would surely have been Terence rather than Plautus. The point was

${ }^{27}$ For the view that the events recounted there belong to the same period as Jerome's dream cf. J. J. Thierry, "The Date of the Dream of Jerome", Vigiliae Christianae 17,1963 , pp. $28-40$. It is oddly suggested by F. F. Schwarz, "Hieronymus flagellatus: UUberlegungen zum literarischen Schlagschatten Ciceros», Acta Antiqua Academiae Scientiarum Hungaricae $30,1982-84$, pp. $363-378$, on p. 373 , n. 31 , that Plautus was chosen because of Jerome's yearning for "die Heiterkeit der Lernjahre».

${ }_{28}$ The incongruity was noted by M. D'Amico, Girolamo di Stridone e le sue epistole: Studio letterario, Acireale 1902, pp. 36-37.

${ }^{2}$ Epist. XXI 13, 9; cf. also in Eph. 6, 4, p. $540^{\wedge}$ (written within two years of the Libellus). Jerome was of course a priest himself.

${ }^{30}$ Viz. epist. CXXV 12, 1 (post Quintiliani acumina Ciceronisque fluuios grauitatemque Frontonis et lenitatem Plinii); praef. Vulg. Dan. p. 6, 12-13 (post Quintiliani et Tulli lectionem ac flores rethoricos); in Gal. lib. III praef. p. $399^{\text {C.D }}$ (ex quo in manus meas numquam Tullius, numquam Maro, numquam gentilium litterarum quilibet auctor ascendit). The first two passages refer specifically to Jerome's decision to learn Hebrew; it is argued by the present writer, "Gregory of Nazianzus and Jerome: Some Remarks", in M. A. Flower and M. Toher (edd.), Georgica: Greek Studies in Honour of George Cawkwell, London 1991, pp. 13-24, on p. 16, that this decision was a direct consequence of Jerome's dream. 
made earlier that Jerome's familiarity with this writer was infinitely greater ${ }^{31}$. Along with Cicero, Vergil and Sallust he was one of the staple authors on the school curriculum and a model of style ${ }^{32}$. In particular as puri sermonis amator ${ }^{33}$ Terence would have provided an immeasurably finer contrast than Plautus with the sermo incultus of scripture. It will nonetheless be argued below that a philosopher fits the bill even better.

The reason which Lübeck gave for his rejection of the reading Plato was the apparent lack of direct familiarity with this author's work on Jerome's part ${ }^{34}$. Recently however McDermott has argued that someone of Jerome's linguistic flair who had also been a pupil of Donatus may be plausibly assumed to have assembled a library that included pagan writers in Greek even before he set out for the East; it is further suggested that one of these authors was in fact Plato ${ }^{35}$. Courcelle had been more sceptical about Jerome's knowledge of classical Greek literature. However even he had been prepared to acknowledge a certain familiarity with Plato: «il n'a pas lu l'ancienne littérature profane, sauf peut-être quelques dialogues de Platon, en s'aidant d'une traduction» ${ }^{36}$. Courcelle accepts Jerome's account of his initiation into Aristotelian dialectic through Porphyry's Isagoge and the commentaries of Alexander of Aphrodisias (epist. L 1, 3); he locates the episode in the 370's at Antioch (ibid. p. 38). It was during the same period that Jerome had his dream: a study of Plato would be a natural adjunct to such a philosophical apprenticeship.

${ }^{31}$ Cf. n. 10 above.

${ }^{32} \mathrm{Cf}$. J. Fontaine, «Comment doit-on appliquer la notion de genre littéraire à la littérature latine chrétienne du iv ${ }^{\mathrm{e}}$ siècle?», Philologus 132, 1988, pp. 53-73, on p. 55.

${ }^{33}$ Caesar, carm. in Ter. 2.

${ }^{34}$ Cf. $n$. 3 above.

${ }^{35}$ W. C. McDermott, "Saint Jerome and Pagan Greek Literature», Vigiliae Christianae 36, 1982, pp. 372-382, on pp. 372 and 380. Jerome refers to this library at the beginning of his dream narrative: bybliotheca, quam mihi Romae summo studio ac labore confeceram, carere non poteram $(30,1)$. It is clear that Rufinus is distorting the truth for polemical reasons when he minimizes Jerome's knowledge of Greek before his arrival in the East; cf. J. N. D. Kelly, Jerome: His Life, Writings, and Controversies, London 1975, pp. 13-14.

${ }^{36} \mathrm{P}$. Courcelle, Les lettres grecques en Occident de Macrobe à Cassiodore, Paris 1948, p. 111. Cf. also ibid., p. 58: «quoiqu'il ait une idée d'ensemble de l'oeuvre de Platon, il n'est nullement certain qu'il l'ait lue; ou s'il l'a lue, c'est d'une façon très rapide et en s'aidant, pour un texte difficile comme le Timée, de la traduction cicéronienne». Most recently some acquaintance with Greek philosophical texts has been posited by C. Moreschini, "Gerolamo e la filosofia", in A. Ceresa-Gastaldo (ed.), Gerolamo e la biografia letteraria, Genoa 1989, pp. 45-62, on pp. 60-61; he does not however mention Plato. Jerome had read the Timaeus in Greek according to F. M. Brignoli, "L'oscurità del Timeo platonico secondo Cicerone e Girolamo», Giornale Italiano di Filologia 12, 1959, pp. 56-63, on p. 63. 
If Courcelle was inclined to doubt whether Jerome had really read Plato, this incredulity was the result of Jerome's failure to address the profundities of Platonic speculation; he did no more than quote a number of superficial sententiae (ibid. pp. 55-59). It must however be objected that Jerome clearly had no aptitude for theoretical argument of this kind. Accordingly its absence from his works cannot be adduced as evidence to show that he had never read Plato. Jerome's debt to other writers tends in any case to be of a verbal nature: he likes to appropriate striking phraseology ${ }^{37}$. From a Greek source on the other hand this kind of borrowing was difficult; Jerome himself points out that it is hard to make what has been well said in one language sound equally good in another (Chron. Epist. p. 2, 4-5). Whereas one might therefore have expected substantial indebtedness to Plautus, such borrowing would not be likely from Plato. Here it is instructive to compare Jerome's debt to Gregory Nazianzen, which turns out to be similarly slight ${ }^{38}$. In this case however Jerome's familiarity with the author's oeuvre is beyond question.

Jerome was no doubt far more interested in Plato's style than in the content of his works. Jerome was of course a consummate stylist himself. Plato too was second to none as a master of Greek prose; in the Libellus itself Jerome attests to his reputation in the words he uses to describe Philo: Platonici sermonis imitator $(35,8)$. The late fourth century was unanimous in its praise ${ }^{39}$. It was Jerome's objective in the East to acquire a perfect proficiency in Greek; for someone with such literary aspirations there was accordingly no better model than Plato. At the same time in Jerome's account of his dream it is the question of literary style that is at issue: one cannot imagine a better contrast with the sermo incultus of the bible than Plato. For this reason alone the reading Plato is to be preferred over Plautus. In Cicero and Plato Jerome pits the greatest stylists of the Latin and Greek worlds respectively against scripture.

Using Plato to achieve a mastery of Greek will have suggested itself all the more readily since a number of his works were also available in the Latin translations of Cicero. Jerome was thereby able to bring together the best Greek stylist with the best Latin translator: for somebody who was shortly to open his own literary career with a series of

${ }^{37} \mathrm{Cf}$. n. 10 above. In this respect Jerome differs from Ambrose or Augustine.

${ }^{38}$ Cf. art. cit. (n. 30), pp. 22-23.

${ }^{39}$ Cf. E. Orth, "Urteile über Platons Stil», Philologische Wochenschrift 53, 1933, pp. 1020-1023; C. Gronau, De Basilio, Gregorio Nazianzeno Nyssenoque Platonis imitatoribus, Göttingen 1908, p. 71. 
translations from the Greek this combination will have provided the ideal novitiate. In the preface to one of these translations Jerome in fact refers to the example of Cicero's renderings of Plato ${ }^{40}$. Later on Rufinus happens to mention Jerome's possession of a codex... in quo erat unus dialogus Ciceronis et idem ipse Graecus Platonis (apol. adu. Hier. II 11). Such a bilingual codex may well have formed part of the library which Jerome had assembled in Rome and now mentions at the start of his dream narrative. In view of such likely preoccupation with Cicero and Plato it is accordingly no surprise that Jerome should have singled out precisely those two as his preferred reading at the time of his dream.

If Jerome's first contact with Plato is likely to have been in Rome ${ }^{41}$, such acquaintance will certainly have been deepened when he reached the East. There the leading churchmen enjoyed a thorough knowledge of Plato ${ }^{42}$. Jerome lodged in the house of his friend and patron Evagrius at Antioch. Evagrius himself had been a pupil of Libanius ${ }^{43}$; Festugière notes that Libanius «cite - ou imite ou rappelle de façon souvent allusive-, constamment Homère, Platon, Démosthène» ${ }^{44}$. Festugière also concludes that the same authors were read by Libanius' students (ibid. pp. 216-217). Since Jerome was living in the household of someone who had been nurtured on Plato, it was natural that he too should read the same author. In a great centre of Greek culture like Antioch texts of Plato would be available in abundance ${ }^{45}$. There are good grounds for supposing that it was in fact there that Jerome's dream took place ${ }^{46}$.

At the same time Courcelle is clearly right to say that Jerome was not really interested in Plato's thought; his concern was overwhelmingly stylistic. Hitherto this lack of interest in the content has been adduced

${ }^{40}$ Chron. epist. p. 1, 7-8: unde et noster Tullius Platonis integros libros ad uerbum interpretatus est.

4i It may be noted that Ambrose, who of course never went to the East, is assumed to have read Plato in the original by G. Bardy, "La culture grecque dans l'Occident chrétien au Iv ' siècle», Recherches de Science Religieuse 29, 1939, pp. 5-58, on pp. 36-37, and by P. Courcelle, Recherches sur les Confessions de Saint Augustin, Paris $1968_{2}$, pp. 312-319. The question has also been discussed by G. Madec, Saint Ambroise et la philosophie, Paris 1974, pp. 109-132; he is somewhat more sceptical.

${ }^{42}$ Cf. Gronau, op. cit. (n. 39); R. Gottwald, De Gregorio Nazianzeno Platonico, Breslau 1906. Jerome was to become Gregory Nazianzen's student.

${ }^{43}$ Socrates, $h$. e. VI 3.

44 A. J. Festugière, Antioche païenne et chrétienne: Libanius, Chrysostome et les moines de Syrie, Paris 1959 (Bibl. des écoles franc. d'Ath. et de Rome 194), p. 216.

${ }^{45}$ For a brief evocation of the city's cultural life cf. P. Monceaux, "Saint Jerôme au désert de Syrie. I», Revue des Deux Mondes 58, 1930 (1 ${ }^{\text {er }}$ juillet), pp. 136-157, on pp. 154-156.

46 Cf. Kelly, op. cit. (n. 35), p. 41. 
as a reason why in the Libellus the reading Plato cannot be correct. However it would seem on the contrary that Jerome's unconcern about Plato's philosophic doctrine is in fact an argument in favour of reading Plato: it is precisely because Jerome had no aptitude for philosophy that he is anxious to convey the impression of being thoroughly familiar with Plato.

Jerome's taste for vaunting his expertise in philosophy was as great as his talent for the subject was small. Examples of such braggadocio occur repeatedly throughout Jerome's work ${ }^{47}$ : Rufinus explicitly rebukes him for it (apol. adu. Hier. II 7). A letter that was written just a few months before the Libellus displays the same propensity: quando philosophos legimus (epist. XXI 13,6). In an early and ambitious work like the Libellus itself it is natural that Jerome should be especially eager to impress. Besides lavish citation of scripture this treatise incorporates two Hebrew etymologies $(1,1$ and 21,8$)$ and a Greek sobriquet: altilis $\gamma \varepsilon \hat{\varepsilon} \omega \nu(28,5)^{48}$. The same purpose of letting the audience know that Jerome is doctus utriusque linguae is also served by the mention of Greek authors: Philo and Josephus are named in connection with the description of cenobitic monasticism $(35,8)$. Here Jerome takes the opportunity to compare Philo with Plato. A reference to his own reading of such a difficult Greek philosopher in the account of his dream was particularly calculated to impress. One might quote a supercilious remark of Jerome himself: multo... pars maior est Milesias fabellas reuoluentium quam Platonis libros (in Is. lib. XII praef. 11. 2-3).

Elsewhere Jerome depicts himself as having devoted his youth to the study of philosophy: fac me errasse in adulescentia et philosophorum, id est gentilium, studiis eruditum in principio fidei ignorasse dogmata Christiana (epist. LXXXIV 6, 2) ${ }^{49}$. It would appear that the same self-characterization is also to be found in the Libellus: Jerome's dream takes place ante annos plurimos $(30,1)$, when he was still in his adulescentia $(30,5)$. Again the same sequence is described: philosophy gives place to the study of scripture. One might note further that it was highly appropriate for Jerome to have projected this image of youthful devotion to philosophy in the Libellus, since he is also keen to stress his association

${ }^{47}$ Cf. Courcelle, op. cit. (n. 36), pp. 53-55.

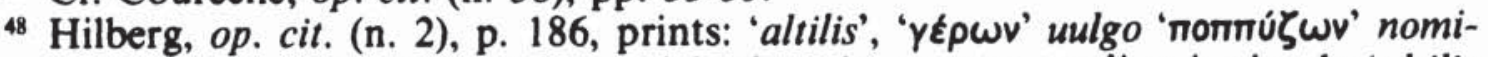
natur. It is argued in a forthcoming article that the correct reading is simply 'altilis $\gamma \varepsilon \rho \omega v$ ' nominatur. On the "préciosité savante avec laquelle Jérôme truffe son latin de mots grecs» cf. P. Lardet, Saint Jérôme: Apologie contre Rufin. Introduction, texte critique, traduction et index, Paris 1983 (SChr. 303), pp. 89*-90* («cette forme de snobisme veut aussi souligner comment Jérôme possède le grecn).

${ }^{49} \mathrm{Cf}$. also adu. Rufin. II 29. The first passage goes on to mention Plato. 
in the East with men like Apollinarius of Laodicea, Gregory Nazianzen and Gregory of Nyssa: all were "philosophers". Moreover if a person such as Ambrose gave the impression of having read Plato ${ }^{50}$, Jerome would naturally want to do the same. It would seem therefore that Jerome's sense of his own incapacity for speculative thought and his consequent intellectual snobbery are alone sufficient to guarantee the reading Plato; Plautus on the other hand would impress no one.

As well as boasting of his own philosophical accomplishments Jerome also makes a habit of condemning philosophy: it is incompatible with Christian truth ${ }^{51}$. If Plato is read in the Libellus, we find a similar standpoint there: philosophy is abandoned in favour of the truth of scripture, as Jerome turns from Plato to an intensive study of the bible in consequence of his dream ${ }^{52}$. In this passage therefore Jerome is parading his proficiency in philosophy and at the same time expressing his scorn for the subject. Both attitudes are entirely in character.

The account of Jerome's dream is introduced with an explicit formulation of the antithesis between scripture and the classics: quid facit cum psalterio Horatius? cum euangeliis Maro? cum apostolo Cicero? (29, 7). Hagendahl observes that "the point in question seems to have been taken over from Tertullian, De praescriptione haereticorum 7: quid ergo Athenis et Hierosolymis? quid Academiae et Ecclesiae?, ${ }^{53}$. Jerome himself refers to Jerusalem at the start of his dream narrative $(30,1)$. It is therefore no surprise that the second of Tertullian's contrasting pairs (Academiae et Ecclesiae) should also find an echo in Jerome's reference to Plato. At a later date Jerome makes Plato part of the antithesis itself: quid Platoni et Petro? (adu. Pelag. I 14) ${ }^{54}$.

Two further examples of this kind of contrast may be cited from Greek writers; both involve Plato. The first occurs in Pseudo-Epipha-

so Cf. n. 41 above.

s1 For Jerome's hostile remarks about philosophers cf. A. S. Pease, "The Attitude of Jerome towards Pagan Literature», Transactions of the American Philological Association 50, 1919, pp. 150-167, on pp. 161-162. Such disparagement conveniently relieves Jerome of the need to come to grips with a subject for which he has no aptitude.

${ }_{52} \mathrm{Cf}$. the concluding words of the dream narrative: tanto dehinc studio diuina legisse, quanto mortalia ante non legeram $(30,6)$.

${ }^{53}$ Op. cit. (n. 8), p. 110, n. 2.

54 Cf. also in Gal. lib. III praef. p. $400^{\mathrm{D}}$ : ecclesia Christi non de Academia et Lyceo sed de uili plebecula congregata est. In the Libellus it was not of course appropriate to include Plato in the antithesis: since Jerome was warning a Latin-speaking public against literary finesse, only Latin authors were suitable there. At the same time this warning takes the form of biblical texts which deal with heretics and unbelievers (viz. II Cor. 6, 14-15; I Cor. 8, 10; Tit. 1, 15; I Tim. 4, 4; I Cor. 10, 20); an ensuing reference to philosophy is therefore highly $\dot{a}$ propos. 


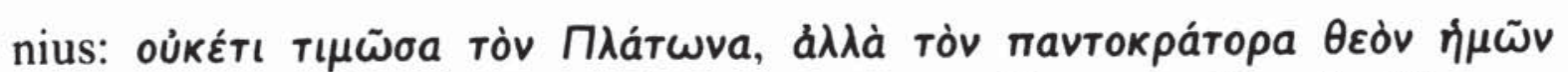
(hom. 1 p. $432^{\mathrm{C}}$ ). The second passage comes from the Pseudo-Chryso-

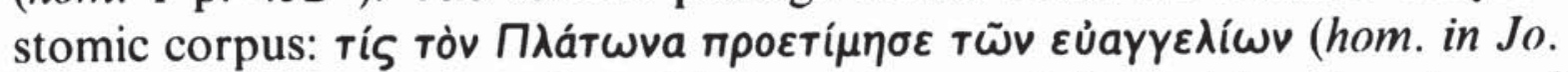
$1: 12$ ). Zellinger argues that this homily was delivered by Severian of Gabala at Constantinople in $380-381^{55}$; Jerome was there at the time. It would accordingly appear that when in the Libellus Jerome contrasts Plato with scripture he is simply reproducing a traditional antithesis ${ }^{56}$.

In Jerome's eyes the philosopher par excellence was Plato: he calls him princeps philosophorum ${ }^{57}$. In the account of his dream Jerome accordingly combines the "prince of philosophers" with the «king of orators", who is of course Cicero: Tullius, qui in arce eloquentiae romanae stetit, rex oratorum (quaest. hebr. in gen. p. 1, 11-12). In this connection it is noteworthy that Jerome has a habit of linking "philosophers" and "orators»: this particular pair in fact constitutes something of a mannerism in Jerome's work ${ }^{58}$. In the present passage of the Libellus the two elements actually form a closer unit than Hilberg's punctuation suggests ${ }^{59}$. One instance of this collocation deserves particular attention; it is virtually contemporaneous with the Libellus. This time Jerome also includes "poets»: ne legas philosophos, oratores, poetas (epist. XXI 13, 8). The context is the same as in the Libellus; here too Jerome is warning against secular literature. Again Jerome has himself in mind: he opens the next sentence with the words nec nobis blandiamur. It is therefore tempting to see in this combination of "poets", "orators" and "philosophers" the same configuration as in the mention of Horace, Vergil, Cicero and Plato in the Libellus.

55 J. Zellinger, Studien zu Severian von Gabala, Münster 1926 (Münst. Beitr. z. Theol. 8), pp. 37-45.

st It may also be noted that Jerome's mention of the "old serpent" three lines later (dum ita me antiquus serpens inluderet) fits a philosopher better than a comic poet: philosophy was traditionally the enemy of christianity.

57 Adu. Pelag. I 15. Cf. also adu. Iouin. I 42 (sapientiae principem).

${ }^{58}$ Cf. (e. g.) epist. XLIX 13, 3; ibid. LIII 4, 2; ibid. LXIX 8, 2; in Ion. III 6 II. 188-190 D.; in Is. X 33, 13 1. 79; tract. in psalm. I p. 891.208 (non misisti oratorem, non misisti philosophum); ibid. I p. 94 II. 125-126; ibid. II p. 387 II. 68-70.

${ }_{59}$ Hilberg punctuates: itaque miser ego lecturus Tullium ieiunabam. post noctium crebras uigilias, post lacrimas, quas mihi praeteritorum recordatio peccatorum ex imis uisceribus eruebat, Plato (he of course prints Plautus) sumehatur in manibus. The full stop after ieiunaham should be replaced with a semicolon. This modification brings out the elegantly chiastic structure of the whole: lecturus Tullium / ieiunabam: post noctium crebras uigilias... / Plato sumebatur in manibus. At the same time the sentence is marked by subtle uariatio: the future participle lecturus is succeeded by the preposition post, while the accusative Tullium alternates with the nominative Plato. Within the second half itself there is again chiasmus (noctium / uigilias: lacrimas / quas... recordatio... eruebat) and uariatio (the nominal form noctium and the relative clause quas...). The whole sentence of course follows Behaghel's law. 
A final point may be made. If Plato is the right reading, the possib1lity arises that Jerome could be referring to the Septuagint as much as to the Old Latin version, when he complains of the uncouthness of scripture in the following sentence. The language of the Greek bible was in fact despised as awkward and crude ${ }^{60}$; the disparity between it and Plato will accordingly have appeared as great as that between the Old Latin and Cicero. If then Jerome's readers will have thought in the first place of the inelegance of the Latin bible, he himself may also have been recording his distaste for the Septuagint. It has been suggested elsewhere that Jerome decided to learn Hebrew as a direct result of his dream $^{61}$. This explanation of his remarkable decision to tackle the original language of scripture would seem to be all the more likely, if Jerome is here expressing dissatisfaction with both the Greek and Latin versions.

The results of the present enquiry may be summarized. All the biographies of Jerome tell how the saint was accustomed to read Plautus during his sojourn in the East. It would seem however to be clear from the foregoing that there are no grounds whatsoever for adopting the reading Plautus in the pertinent passage of the Libellus de uirginitate; on the other hand there is every reason to suppose that Plato was in fact what Jerome wrote. Henceforth Plautus must accordingly be banished from the text of this work. He must also disappear from biographies of the saint.

NeIL AdKIN

"60 CF. the present writer, «Some Notes on the Dream of Saint Jerome», Philologus 128, 1984, pp. 119-126, on p. 122.

${ }^{61}$ Cf. $n .30$ above. 